\title{
Educator Attitude and Servant Leadership: A Positive Combination for Students with Disabilities
}

\author{
Karitta A. Page, Ed.D. \\ Chesapeake Public Schools \\ 1968 Bruin Place \\ Chesapeake, VA 23321 \\ USA \\ Linda D. Grooms, Ph.D. \\ Regent University \\ 1000 Regent University Drive \\ Virginia Beach, VA 23464 \\ USA
}

\begin{abstract}
This study examined the relationship between educator attitude towards students with disabilities and their selfperception of servant leadership characteristics related to teaching students with mild to moderate disabilities included in the general education classroom. Using the Attitude Towards Teaching All Students Scale (ATTAS-mm) combined with the Servant Leadership Questionnaire (SLQ), a sampling frame of 166 secondary educators who teach students with mild to moderate disabilities in the general education setting within one southeastern Virginia school division were surveyed. While a small positive correlation existed between servant leadership and educator attitude as evidenced by the Pearson $r$ scores ranging from .250 to .282, multiple regression determined that three of the five servant leadership factors (i.e., emotional healing; $B=.672$, wisdom; $B=.571$, and organizational stewardship; $B=.312$ ) could reliably predict educator attitude, thus indicating that higher perceived levels of servant leadership combined with greater positive educator attitudes is a winning combination for students with mild to moderate disabilities.
\end{abstract}

Key Words: teacher attitude, servant leadership, inclusion, students with disabilities, professional development, teacher pre-service training

\section{Introduction}

According to the National Center for Education Statistics (2019), the percentage of students ages 6-21 served under the Individuals with Disabilities Education Act who spend $80 \%$ or more of their day in the general education setting, increased from $47 \%$ in fall 2000 to $63 \%$ in fall 2017, and although implementation of federal mandates was to ensure equal access and fair treatment of individuals with disabilities, long-standing assumptions and stereotypes continue (Boroson, 2017). In fact, students with mild to moderate disabilities are often placed in general education settings whether or not the teacher holds a favorable attitude towards ensuring their success (Gregory et al., 2016). A vital component and the most important school-based determinant to the fidelity and equity of educational practices for the academic success of these students (Avramidis \& Norwich, 2002; Campbell et al., 2017; Costley, 2013; de Boer et al., 2012; Miller, 2012) is the teacher who plans meaningful lessons, delivers engaging instruction, and assesses individual learning. In their study of 774 general and special educators focusing on the differences in elementary and secondary classroom structure and teacher efficacy in serving these students, Shippen et al. (2011) found that many teachers feel inadequately prepared, often leading to negative attitudes.

\section{Background/Literature Review}

In their study on teacher attitudes towards special education inclusion practices, Hammond and Ingalls (2003) suggested that attitudes have the potential to impact the success of these practices in the classroom. Boyle et al. (2013) specifically found that teachers reported more positive attitudes when they received the necessary training required to work with students with disabilities. Although many pre-service educators improve their inclusive attitudes after exposure to distinct preparation programs (Rosenzweig, 2009), these programs have continued to face ongoing scrutiny regarding whether their pre-service teachers and graduates are adequately prepared to meet the needs of the increasingly diverse classroom (Gregory \& Noto, 2018). 


\subsection{Educator Attitude Towards the Inclusion of Students with Disabilities}

The movement towards "the inclusion of diverse learners into the general [education] setting has not always been echoed by increased knowledge, collaboration, or [even] pre-service experiences....[One must take into account the educator's attitude, which is profoundly influenced by] their beliefs about their own ability to educate diverse learners in the general education classroom" (Fuchs, 2009, p. 30). These attitudes can have a significant effect on a student's academic performance (Cassady, 2011; Chimhenga, 2016). While special education has progressed into a program that seeks to promote equity and access to all aspects of schooling, the community, and society, challenges remain (Salend \& Duhaney, 2011).

\subsubsection{Inclusion}

Although national policy sets an agenda for educating students in the least restrictive environment (LRE), the term inclusion is not mentioned in any U.S. educational legislation; hence, controversies remain about the effectiveness of special education and the appropriate use of inclusive practices (Hossain, 2012). Research (Kozleski et al., 2015; McLeskey \& Waldron, 2002; Rea et al., 2002) has shown that within a single district, inclusive educational practices can vary within school districts, buildings, and classrooms. While federal funding is appropriated to assure that students are afforded a free and appropriate public education (FAPE) in the LRE, it is still no guarantee that inclusive services will be provided, nor does it ensure that the inclusion effort will be successful (Gregory \& Noto, 2012).

\subsubsection{Attitude}

In his empirical validation of affect, behavior, and cognition as distinct components of attitude, Breckler (1984) revealed that each should be individually measured due to the ambiguous nature of the overall term. Mirroring Breckler, in their three-component model, Eagly and Chaiken (1993) slightly modified these components referring to them as affective, behavioral, and cognitive. While the affective component involves one's feelings and/or emotions, the behavioral manifests itself in the way one acts. On the other hand, the cognitive reflects a person's beliefs or knowledge about an individual, object, or situation. Generally, people who have a positive attitude tend to have favorably aligned attitudinal components, whereas those with negative attitudes do not.

Educators' attitudes towards teaching students with disabilities are an important aspect of inclusion because if teachers are not accepting of the process, then their commitment to ensuring it is implemented successfully may be compromised (Ernst \& Rogers, 2009; Schmidt \& Vrhovnik, 2015). Gregory and Noto (2018) remind us that "despite their entry into the physical space of general education classrooms and the expected instruction of the core academic standards, students with disabilities may still be excluded" (p. 1). Although many variables may affect schools' and districts' abilities to successfully implement educational initiatives, numerous studies (Boyle et al., 2013; de Boer et al., 2011; Galaterou \& Antoniou, 2017; Kimble, 2017; van Reusen et al., 2001; Wilson, 2014) have shed light on the impact teacher attitude has on inclusive educational practices.

\subsection{Servant Leadership}

In 1977, Greenleaf crystallized the term servant leadership, while emphasizing the ideal of service in the leaderfollower relationship (van Direndonck, 2011). Demonstrating its key elements--listening, empathy, healing, persuasion, awareness, foresight, conceptualizing, commitment to growth, stewardship, and community building (Spears, 1998)--servant leadership moves the focus away from the more traditional autocratic and hierarchical models of leadership toward a more ethical and caring way of being in relationship with others (Spears, 2010). While clustering and operationalizing the servant leadership factors into five categories--altruistic calling, emotional healing, wisdom, pervasive mapping, and organizational stewardship--Barbuto and Wheeler (2006) validated Spears' work indicating that it provided "the closest representation of an articulated framework for what characterizes servant leadership" (p. 302).

In her work with educators on a servant leader approach as an effective model for students, Drury (2005) determined that educators who exercise characteristics of servant leadership are better equipped to have a classroom where more effective learning for students occurs and more satisfying teaching for faculty follows. Fitzgerald (2015) later noted that "teachers who adopt servant leadership and apply its principles in their classrooms are more equipped to help students face daily obstacles by turning away from authoritative instructional techniques towards a more all-encompassing, communal approach to learning" (p. 75). Noland and Richards (2015) called this servant teaching indicating that it "capitalizes on the altruistic nature of teaching as 'student-centered' by focusing on 'follower-development"' (p. 26). Additionally, they suggested servant leadership/teaching is well positioned to provide educators with a set of tools to improve student indicators of learning and engagement.

\subsection{Educator-Servant Leadership Connection}

Extending the work of Spears (1998), Crippen (2005) found a direct link between the characteristics of the servant leader and the role of an educator. Hays (2008) later contended that the successful teacher is a servant first, 
espousing that those who take on the persona of a servant leader not only leave an impression on students, but also improve their overall academic environment. Crippen (2010) further supported this notion of shifting the focus of the educator's mindset towards a more service-orientation, while indicating that the concept of servant leadership may provide the seeds for developing effective and supportive learning environments for all learners. Furthering Crippen's idea of servant leadership in the classroom, Noland and Richards (2015) agreed that applying principles of servant leadership in the classroom "serves as an opportunity to improve education by positively impacting student learning, development, and deepening the student-centeredness of instruction" (p. 1) as well as increasing student motivation and engagement, thus supporting servant leadership as a viable approach for teaching.

\section{Methodology}

Two research questions and their accompanying hypotheses catapulted this study:

RQ 1: Is there a statistically significant relationship between servant leadership factors (altruistic calling, emotional healing, wisdom, persuasive mapping, and organizational stewardship) and teacher attitude towards inclusion of students with mild to moderate disabilities in the general education setting?

$\mathbf{H}_{\mathbf{0 1}}$ : There is no statistically significant relationship between servant leadership factors and teacher attitude towards inclusion of students with mild to moderate disabilities in the general education setting.

RQ 2: Do servant leadership factors (altruistic calling, emotional healing, wisdom, persuasive mapping, and organizational stewardship) predict teacher attitude?

$\mathbf{H}_{\mathbf{0} 2}$ : Servant leadership factors do not predict teacher attitude.

\subsection{Population and Sample}

From the larger population of 1,613 middle and high school teachers in one southeastern Virginia school division, only special and general educators who currently taught students with disabilities in the general education setting were eligible to participate. To determine the sample of who was and who was not eligible to participate, a census method was employed and a random distribution was anticipated.

\subsection{Instrumentation}

A comprehensive literature review resulted in determining Gregory and Noto's (2012) Attitude Towards Teaching all Students Scale (ATTAS-mm) and Barbuto and Wheeler's (2006) Servant Leadership Questionnaire (SLQ) as the ideal instruments available for this study. Considering ease of survey completion, the ATTAS-mm and the $S L Q$ were combined to create one 48 -item survey inclusive of 16 demographic questions.

\section{Results}

During a 3-week data collection period, among the 1,613 educators who could have participated, 166 responded to the combined ATTAS- $\mathrm{mm} / S L Q$, yielding a $10.3 \%$ participation rate. The low response rate could possibly be attributed to several factors. First, perhaps due to a variety of reasons all administrators did not distribute the survey even after several prompts to do so. Second, perhaps the number of items on the survey dissuaded potential respondents from participating. Third, perhaps the timing of the survey dissemination (i.e., COVID-19 concerns) was a factor. With the low response rate, systemic bias may have been present, thus the statistical significance in this study should be interpreted with caution.

Among those who participated, 27.7\% $(n=46)$ were middle school teachers and $72.3 \%(n=120)$ taught high school. The majority $(69.3 \% ; n=115)$ were general educators instructing students with disabilities, while $30.7 \%(n$ $=51)$ were special educators. The majority $(78.3 \% ; n=130)$ taught students with disabilities in the core content areas of math, science, social studies, and English, while only $21.7 \%(n=36)$ indicated teaching elective classes (e.g., art, music, and physical education).

\subsection{Attitude}

Nine items on the combined ATTAS- $\mathrm{mm} / \mathrm{SL} Q$ measured three components of attitude: affective (i.e., developing personal and professional relationships), behavioral (i.e., creating an accepting environment for all students to learn, and cognitive (i.e., believing all students can succeed in general education classrooms). Each question required a judgment as perceived by the respondent using a 7-point Likert scale ranging from 1 (Disagree Very Strongly) to 7 (Agree Very Strongly). The mean scores for each attitude factor were affective, 14.7771; behavioral, 16.0663; and cognitive, 10.4458, while the overall mean score for attitude was 41.2892 with a standard deviation of 5.94221 . 
Responses to the questions focusing on the affective aspect of attitude identified that the majority of the respondents agreed that they would like to be mentored by teachers who model effective differentiated instruction; they wanted to emulate teachers who know how to design appropriate academic interventions; and they believed including students with mild to moderate disabilities in the regular education classroom was effective because they could learn the social skills necessary for success. Not surprisingly, when queried regarding the behavioral component of attitude, most respondents indicated that all students with mild to moderate disabilities should be educated in regular classrooms with non-disabled peers to the fullest extent possible. In contrast, the cognitive component responses showed most respondents agreed that most or all separate classrooms that exclusively serve students with disabilities should not be eliminated. Because this conclusion is in sharp contrast to that of the behavioral responses, one can speculate that the wording of the questions may have been somewhat unclear and ambiguous.

\subsection{Servant Leadership Factors}

The final section of the combined ATTAS- $\mathrm{mm} / S L Q$ measured servant leadership using Barbuto and Wheeler's (2006) $S L Q$, with a few wording modifications to reflect the educational environment. Twenty-three items measured five servant leadership factors: altruistic calling, emotional healing, wisdom, persuasive mapping, and organizational stewardship. These questions also required a judgment based upon a 5-point Likert scale, this time ranging from 1 (Never) to 5 (Always). Questions pertaining to altruistic calling, pervasive mapping, and wisdom mainly yielded responses of often (4), while those focusing on emotional healing were equally often (4) and sometimes (3). Lastly, the majority of responses were often (4) and always (5) for questions focusing on organizational stewardship.

Mean scores and standard deviations were also calculated for each of the two continuous variables: educator attitude $(\mathrm{M}=41.29, \mathrm{SD}=5.94, \mathrm{~N}=166)$ and servant leadership $(\mathrm{M}=93.54, \mathrm{SD}=8.88, \mathrm{~N}=166)$. In addition, for each servant leadership factor, responses to the corresponding categorical statements were calculated for mean score: altruistic calling, 17.5723; emotional healing, 14.7590; wisdom, 20.2530; persuasive mapping, 19.0602; and organizational stewardship, 21.8916.

\subsection{Assumptions for Research Question 1}

Associated with a Pearson product-moment correlation coefficient are underlying assumptions and requirements used to determine significance. The first assumption was to determine if there was a linear relationship between the variables attitude and servant leadership. A visual inspection of a scatterplot determined that a linear relationship between the two did exist; however, boxplots revealed no extreme outliers. Due to the sample size $(\mathrm{N}>50)$ and to determine if the variables were normally distributed, a Kolmogorov-Smirnov test was conducted. The test results for the variable educator attitude were found tenable, $\mathrm{D}(166)=.067, \mathrm{p}>.05$; however, the findings for servant leadership were found not tenable, $\mathrm{D}(166)=.108, \mathrm{p}<.05$. To further substantiate normality for servant leadership, a histogram was used to illustrate a normal distribution. The scores appeared to be reasonably normally distributed, which was also supported by an inspection of the normal probability plots for educator attitude and servant leadership.

\subsection{Assumptions for Research Question 2}

Associated with multiple regression, several assumptions also needed to be met in order to determine if the data could be analyzed. For example, to determine the assumption of linearity, partial regression plots as well as a plot of studentized residuals against the predicted values were evidenced. The independence of observation assumption was evaluated using the Durbin-Watson statistic. Generally, to support independence of observations, the $d$ coefficient should be between 1.5 and 2.5 (Rovai et al., 2014). The $d$ coefficient in this study was 1.716 confirming an independence of residuals. Also, as assessed by visual inspection of a plot of studentized residuals versus unstandardized predicted values, there was homoscedasticity. There was no evidence of multicollinearity, as assessed by tolerance values greater than 0.1 and values for Cook's distance above 1. As assessed by Q-Q Plots, the assumption of normality was met.

\subsection{Research Question 1 Results}

Based upon the Pearson, the relationship between overall attitudinal components and overall servant leadership factors was $r(164)=.248, \mathrm{p}=.001$, which showed that there was a small, yet statistically significant, correlation between educator attitude and servant leadership. Servant leadership statistically explained $6 \%$ of the variability in educator attitude. There were also small positive correlations between educator attitude and altruistic calling, $r(164)$ $=.250$; educator attitude and emotional healing, $r(164)=.261$; and educator attitude and organizational stewardship, $r(164)=.282($ see Table 1$)$. 
Table 1 Correlation Between Overall Attitude and Servant Leadership

\begin{tabular}{llllll}
\hline Variable & $\begin{array}{l}\text { Altruistic } \\
\text { calling }\end{array}$ & $\begin{array}{l}\text { Emotional } \\
\text { healing }\end{array}$ & Wisdom & $\begin{array}{l}\text { Persuasive } \\
\text { mapping }\end{array}$ & $\begin{array}{l}\text { Organizational } \\
\text { stewardship }\end{array}$ \\
\hline Educator attitude & $.250^{* *}$ & $.261^{* *}$ & .021 & .104 & $.282^{* *}$ \\
\hline
\end{tabular}

**Correlation is significant at the .01 level, two-tailed

Additionally, this conclusion was supported by a small positive correlation between the affective component and altruistic calling, $r(164)=.198$; the affective component and emotional healing, $r(164)=.182$; the behavioral component and emotional healing, $r(164)=.286$; and the cognitive component and organizational stewardship, $r(164)=.241$. There was also a moderate positive correlation between the affective component and organizational stewardship, $r(164)=.324$, and the behavioral component and altruistic calling, $r(164)=.331$ (see Table 2).

Table 2 Correlation Between Attitudinal Components and Servant Leadership

\begin{tabular}{llllll}
\hline $\begin{array}{l}\text { Variable/ } \\
\text { Component }\end{array}$ & $\begin{array}{l}\text { Altruistic } \\
\text { calling }\end{array}$ & $\begin{array}{l}\text { Emotional } \\
\text { healing }\end{array}$ & Wisdom & $\begin{array}{l}\text { Persuasive } \\
\text { mapping }\end{array}$ & $\begin{array}{l}\text { Organizational } \\
\text { stewardship }\end{array}$ \\
\hline Affective & $.198^{* * * *}$ & $.182^{* *}$ & -.013 & .103 & $.324^{* * *}$ \\
Behavioral & $.331^{* *}$ & $.286^{* *}$ & .071 & .086 & $.083^{* * *}$ \\
Cognitive & .044 & .124 & -.010 & .048 & $.241^{*}$ \\
\hline
\end{tabular}

* Correlation is significant at the .05 level, two-tailed

**Correlation is significant at the .01 level, two-tailed

The data were also grouped by core and elective teachers. The relationship between the overall attitudinal components and overall servant leadership factors for core content area teachers was $r(128)=.282, \mathrm{p}=.001$, which showed that there was a small, yet statistically significant, correlation between educator attitude and servant leadership among this group. However, the results for the relationship between the overall attitudinal components and overall servant leadership factor for elective teachers was $r(34)=.279, \mathrm{p}=.099$, which showed that there was not a statistically significant correlation between educator attitude and servant leadership for this category of teachers.

Additionally, for core teachers, this analysis showed a small positive correlation between the affective component and altruistic calling, $r(128)=.217$ and the affective component and emotional healing, $r(128)=.196$. There was also a moderate positive correlation between the affective component and organizational stewardship, $r(128)=.353$ (see Table 3).

Table 3 Correlations Between Attitudinal Components and Servant Leadership Components for Core Teachers

\begin{tabular}{llllll}
\hline $\begin{array}{l}\text { Variable/ } \\
\text { Component }\end{array}$ & $\begin{array}{l}\text { Altruistic } \\
\text { Calling }\end{array}$ & $\begin{array}{l}\text { Emotional } \\
\text { Healing }\end{array}$ & Wisdom & $\begin{array}{l}\text { Persuasive } \\
\text { Mapping }\end{array}$ & $\begin{array}{l}\text { Organizational } \\
\text { Stewardship }\end{array}$ \\
\hline Affective & $.217^{* *}$ & $.196^{* *}$ & .029 & .138 & $.353^{* * *}$ \\
Behavioral & $.351^{* *}$ & $.338^{* *}$ & .139 & $.176^{*}$ & $.306^{* * *}$ \\
Cognitive & .040 & .105 & -.047 & .014 & .060 \\
\hline
\end{tabular}

* Correlation is significant at the 0.05 level, two-tailed

** Correlation is significant at the 0.01 level, two-tailed

Analysis for elective teachers showed only a moderate positive correlation between the affective component and organizational stewardship, $r(34)=.345$ (see Table 4).

Table 4 Correlations Between Attitudinal Components and Servant Leadership Components for Elective Teachers

\begin{tabular}{lllccl}
\hline $\begin{array}{l}\text { Variable/ } \\
\text { Component }\end{array}$ & $\begin{array}{l}\text { Altruistic } \\
\text { Calling }\end{array}$ & $\begin{array}{l}\text { Emotional } \\
\text { Healing }\end{array}$ & Wisdom & $\begin{array}{l}\text { Persuasive } \\
\text { Mapping }\end{array}$ & $\begin{array}{l}\text { Organizational } \\
\text { Stewardship }\end{array}$ \\
\hline Affective & .239 & .233 & -.076 & .091 & $.345^{*}$ \\
Behavioral & .332 & .168 & -.111 & -.154 & .081 \\
Cognitive & .147 & .324 & .260 & .320 & .308 \\
\hline
\end{tabular}

* Correlation is significant at the 0.05 level, two-tailed

**Correlation is significant at the 0.01 level, two-tailed

\subsection{Research Question 2 Results}

Multiple regression using the "enter method" (i.e., the default setting in SPSS 26 that forces all independent variables into the equation in one step) was used to evaluate the null hypothesis that servant leadership factors (altruistic calling $(M=17.57, S D=2.05)$, emotional healing $(M=14.76, S D=2.05)$, wisdom $(M=20.25$, 
$\mathrm{SD}=2.17)$, persuasive mapping $(\mathrm{M}=19.06, \mathrm{SD}=2.61)$, and organizational stewardship $(\mathrm{M}=21.89, \mathrm{SD}=2.41)$ do not predict educator attitude $(M=41.29, \mathrm{SD}=5.94)$. However, the multiple regression model predicted attitude with statistical significance, $\mathrm{F}(5,160)=6.655, \mathrm{p}<.05$, adj. $\mathrm{R}^{2}=.146 . \mathrm{R}^{2}$ for the overall model was $17.2 \%$ with an adjusted $\mathrm{R}^{2}$ of $14.6 \%$, a medium size effect according to Cohen (1988). All five independent variables were not statistically significant since $\mathrm{p}>.05$ for altruistic calling and persuasive mapping; therefore, making them insignificant slope coefficients. P-values greater than the significance levels indicated that there was insufficient evidence in the sample to conclude that a non-zero correlation existed.

Emotional healing, wisdom, and organizational stewardship variables were statistically significant because $\mathrm{p}<.05$. The two non-statistically significant independent variables were removed from the regression equation. The unstandardized regression equation for predicting educator attitude was $\mathrm{Y}^{1}=.67 \mathrm{x}_{1}-.57 \mathrm{x}_{2}+.65 \mathrm{x}_{3}+26.92$. Regression coefficients and standard errors can be found in Table 5.

Table 5 Coefficients and Collinearity Statistics

\begin{tabular}{|c|c|c|c|c|c|c|c|}
\hline & Unstandardized & Coefficients & $\begin{array}{l}\text { Standardized } \\
\text { coefficients }\end{array}$ & & & & \\
\hline Model & B & $S E$ & Beta & $t$ & Sig. & Tolerance & VIF \\
\hline (Constant) & 26.921 & 5.086 & & 5.293 & .000 & & \\
\hline Altruistic calling & .438 & .247 & .151 & 1.772 & .078 & .715 & 1.398 \\
\hline Emotional healing & .672 & .226 & .302 & 2.974 & .003 & .503 & 1.986 \\
\hline Wisdom & -.571 & .254 & -.209 & -2.251 & .026 & .602 & 1.662 \\
\hline Persuasive mapping & -.312 & .243 & -.137 & -1.283 & .201 & .453 & 2.209 \\
\hline $\begin{array}{l}\text { Organizational } \\
\text { stewardship }\end{array}$ & .652 & .205 & .265 & 3.178 & .002 & .747 & 1.339 \\
\hline
\end{tabular}

Concerning the research questions and the associated null hypotheses, the following decisions were made. Reject $\mathrm{H}_{\mathrm{o} 1}$ on the basis of the evidence in the Pearson product-moment correlation and reject $\mathrm{H}_{\mathrm{o} 2}$ on the basis of the evidence in the multiple regressions.

\section{Discussion}

With only a $10.3 \%(n=166)$ response rate based on a targeted audience of 1,613 teachers, the results should be considered with caution. While research (Dessemontet et al., 2012; Hudson et al., 2013; McKee, 2011) indicated that academic and social outcomes can be improved for students with mild to moderate disabilities by including them in the general education setting, it is important that these students are paired with educators who are willing to provide for their needs. Crippen (2010) explained that a positive mindset and attitude towards service in education provides the framework for developing effective and supportive learning environments, and since the principles of servant leadership involve creating and sustaining faculty-student relationships in order that teachers are able to seize daily opportunities for making a positive difference in the lives of their students (Bowman, 2005), infusing servant leadership into educators' attitudes is necessary.

\subsection{Relationship between Servant Leadership and Educator Attitude}

A small positive correlation, $r(164)=.248, \mathrm{p}=.001$ between servant leadership and educator attitude was found; therefore, the null hypothesis was rejected. In this study, respondents who perceived a high level of servant leadership indicated greater agreement in their attitude towards teaching students with mild to moderate disabilities in the general education setting.

From the educator's perspective, the majority of the servant leadership factors (i.e., altruistic calling, emotional healing, and organizational stewardship) had a small but positive correlation with the overall measure of educator attitude as evidenced by the Pearson $r$ scores ranging from .250 to .282. Furthermore, when looking at the separate factors of servant leadership and educator attitude, the strongest correlation between two constructs was the behavioral component of attitude and altruistic calling, $r(164)=.331$, which provided a moderate positive correlation. 
Additionally, there was a moderate positive correlation between the affective component of attitude and organizational stewardship $r(164)=.324$. Since the affective component of attitude involves a person's feelings or emotions, this would suggest that the more positive the attitude, the more likely the focus on relational aspects of promoting others to make positive contributions supporting Black's (2010) study on servant leadership and school climate.

When comparing the results of core and elective teachers, the Pearson product-moment correlation revealed that a small positive correlation, $r(128)=.282, \mathrm{p}=.001$, existed among educator attitude and servant leadership for core teachers. However, a non-statistically significant correlation, $r(34)=.279, \mathrm{p}=.099$, existed for elective teachers, which was in sharp contrast to Pritchard's (2014) study in which she found that elective teachers were more accepting of students with disabilities than core content area educators.

\subsection{Servant Leadership Prediction of Teacher Attitude}

While the servant leadership model did predict educator attitude with statistical significance, $\mathrm{F}(5,160)=6.655, \mathrm{p}<$ .05 , adj. $\mathrm{R}^{2}=.146$, all five variables did not add statistical significance to the prediction. Instead only three servant leadership factors (i.e., emotional healing; $\mathrm{B}=.672$, wisdom; $\mathrm{B}=.571$, and organizational stewardship; $\mathrm{B}=.312$ ) could reliably predict educator attitude. While this model explained $14.6 \%$ of the variance in educator attitude, emotional healing made the strongest unique contribution in its explanation. Therefore, the second null hypothesis was also rejected, supporting Shek and Chai's (2019) earlier research that not only validated a measure of attitude and service leadership, but also found that a positive attitude linked to service leadership develops successful leadership qualities. Since this study revealed that servant leadership factors could predict educator attitude, further exploration of the two constructs to predict attitudes seems promising for current and future educators.

\subsection{Implications}

First, this study highlighted the importance of servant leadership factors and educator attitude when teaching students with disabilities in the general education setting. To foster positive attitudes within the changing landscape of inclusive practices, school divisions may need to refocus their professional training for teachers to include the concept of servant leadership. While Fields et al. (2015) reinforced the infusion of servant leadership in pre-service education programs, this study suggests that the servant leadership philosophy could be introduced to both new and current educators.

Second, using the tenets of servant leadership, educational leaders should be able to sculpt a vision towards providing a holistic educational experience for all students (Black, 2010). Showing a correlation between educator attitude and servant leadership, this study supported Drury's (2005) research that indicated "teachers do function as leaders, and servant leadership is the best leadership mindset for the classroom" (p. 9). With that in mind, it would be beneficial for these leaders to select teachers who possess high servant leadership qualities coupled with positive attitudes toward teaching all students to both hold leadership positions within the building and to mentor first-year educators.

Third, supporting the work of Crippen (2005) and Gregory and Noto (2019), this study reinforced the importance of both educator attitude and servant leadership when working with students with disabilities in the general education setting, providing a foundation for those educators who deal with a diverse population of students. For example, Crippen (2005) purported that "the concepts of inclusivity, empathy, acceptance, and foresight fit nicely into a servant leadership model and provided a positive, proactive mindset when dealing with special needs students and their parents" (p. 11). Furthering this thought, Gregory and Noto (2019) concluded that educators must be confident in their ability to teach students with disabilities, while maintaining a positive attitude towards including them in the general education setting. This study further suggested that the use of attitudinal data may also be able to assist educational leaders in selecting and hiring those individuals with the characteristics needed to adequately serve these students.

\subsection{Recommendations for Future Research}

While this study added to the existing literature on educator attitude and servant leadership, further research is still warranted, particularly to facilitate a higher response rate.

Recommendations for future research include replicating the study with a larger sample size; replicating the study surveying elementary teachers and possibly include instructional support staff; consider extending the data collection period; consider using both online and in-person survey collection methods; consider a mixed methods design to include teacher interviews to provide practical feedback on the functioning of students with disabilities and how the teacher's attitude is impacted by incorporating or using the principles of servant leadership; and shortening the survey instrument. 


\section{Conclusions}

Recognizing that teaching is a service profession, individuals entering, as well as those already in the field, must understand their responsibilities for the total development and functioning of all students. To facilitate this, understanding the relationship between teacher attitude towards teaching students with disabilities and servant leadership factors may prove beneficial to ensure student success as it affords educators the opportunity, if applied with integrity, to utilize classrooms for relationship-based empowerment instead of teaching students from a sense of authoritarianism (Herman \& Marlowe, 2005). When teachers show empathy and caring, express personal consideration, and offer intellectual stimulation, motivation, and inspiration, student satisfaction, retention, and success increase (Sahawneh \& Benuto, 2018). While the servant approach to teaching has been found to positively influence overall student learning and engagement (Noland \& Richard, 2015), more specific previous research (de Boer et al., 2011; Hammond \& Ingalls, 2003; Kahn \& Lewis, 2014; Leatherman \& Niemeyer, 2005) indicated that teacher attitude is crucial in the success of the inclusive classroom. This study confirms these findings.

\section{References}

Avramidis, E., \& Norwich, B. (2002). Teachers' attitudes towards integration/inclusion: A review of the literature. European Journal of Special Needs Education, 17(2), 129-147.

Barbuto, J. E., \& Wheeler, D. W. (2006). Scale development and construct clarification of servant leadership. Group \& Organization Management, 31(3), 300-326. https://doi.org/10.1177\%2F1059601106287091

Black, G. L. (2010). Correlational analysis of servant leadership and school climate. Journal of Catholic Education, 13(4), 437-466.

Boroson, B. (2017). Inclusive education: Lessons from history. Educational Leadership, 74(7), 18-23.

Bowman, R. F. (2005). Teacher as servant leader. The Clearing House: A Journal of Educational Strategies, Issues and Ideas, 78(6), 257-260.

Boyle, C., Topping, K., \& Jindal-Snape, D. (2013). Teachers' attitudes towards inclusion in high schools. Teachers and Teaching, 19(5), 527-542.

Breckler, S. J. (1984). Empirical validation of affect, behavior, and cognition as distinct components of attitude. Journal of Personality and Social Psychology, 47(6), 1191.

Campbell, H., Strawser, M. G., \& Sellnow, D. D. (2017). Addressing the leadership crisis through servant-infused pedagogy in the college classroom. Journal of Communication and Religion, 40(2), 43-60.

Cassasdy, J. (2011). Teachers' attitudes toward the inclusion of students with autism and emotional behavioral disorder. Electronic Journal for Inclusive Education, 2(7), 1-23.

Chimhenga, S. (2016). Attitudes of teachers towards students with disabilities in mainstream classes: The case of teachers in some selected secondary schools in Zimbabwe. Asian Journal of Educational Research, 4(4), 36-41.

Cohen, J. (1988). Statistical power analysis for the behavioral sciences (2nd ed.). Lawrence-Erlbaum.

Costley, K. C. (2013). Ongoing professional development: The prerequisite for and continuation of successful inclusion meeting the academic needs of special students in public schools. Online Submission. https://files.eric.ed.gov/fulltext/ED541075.pdf

Crippen, C. (2005). The democratic school: First to serve, then to lead. Canadian Journal of Educational Administration and Policy, 47, 1-17.

Crippen, C. (2010). Inclusive education: A servant-leadership perspective. Education Canada, 45(4), 19-22.

de Boer, A., Pijl, S. J., \& Minnaert, A. (2011). Regular primary schoolteachers' attitudes towards inclusive education: A review of the literature. International Journal of Inclusive Education, 15(3), 331-353.

de Boer, A., Timmerman, M., Pijl, S. J., \& Minnaert, A. (2012). The psychometric evaluation of a questionnaire to measure attitudes towards inclusive education. European Journal of Psychology of Education, 27(4), 573589.

Dessemontet, R., Bless, G., \& Morin, D. (2012). Effects of inclusion on the academic achievement and adaptive behavior of children with intellectual disabilities. Journal of Intellectual Disability Research, 56, 579-587.

Drury, S. (2005). Teacher as servant leader: A faculty model for effectiveness with students. [Conference Session]. Regent University School of Leadership Studies Servant Leadership Research Roundtable, Virginia Beach, VA, United States. http://www.drurywriting.com/sharon/drury_teacher_servant.pdf

Eagly, A. H., \& Chaiken, S. (1993). The psychology of attitudes. Harcourt Brace.

Ernst, C., \& Rogers, M. (2009). Development of the inclusion attitude scale for high school teachers. Journal of Applied School Psychology, 25(3), 305-322.

Fields, J. W., Thompson, K. C., \& Hawkins, J. R. (2015). Servant leadership: Teaching the helping professional. The Journal of Leadership Education, 14(4), 92-105. https://journalofleadershiped.org/wpcontent/uploads/2019/02/14_4_Fields.pdf

Fitzgerald, R. J. (2015). Becoming Leo: Servant leadership as a pedagogical philosophy. Critical Questions in Education, 6(2), 75-85. 
Fuchs, W. W. (2009). Examining teachers' perceived barriers associated with inclusion. Strategy Journal, 19(1), 30-35.

Galaterou, J., \& Antoniou, A. S. (2017). Teachers' attitudes towards inclusive education: The role of job stressors and demographic parameters. International Journal of Special Education, 32(4), 643-658.

Gregory, J. L., McCoy, T. A., Baker, M. F., \& Fedigan, A. L. (2016). Using educator characteristics on attitudes toward inclusion to drive professional development. Journal of Advances in Education Research, 1(1), 2031.

Gregory, J. L., \& Noto, L. A. (2012). Technical manual for Attitudes Towards Teaching all Students (ATTAS-mm) instrument [Conference session]. CEC TED Conference, Grand Rapids, MI, United States. https://files.eric.ed.gov/fulltext/ED537530.pdf

Gregory, J. L., \& Noto, L. A. (2018). Attitudinal instrument development: Assessing cognitive, affective, and behavioral domains of teacher attitudes toward teaching all students. Cogent Education, 5, 1-12.

Gregory, J. L., \& Noto, L. A. (2019). Revalidating an instrument to gain insights into changing attitudes towards teaching all students [Conference session]. Northeastern Educational Research Association Annual Conference, Trumbull, CT, United States.

Hammond, H., \& Ingalls, L. (2003). Teachers' attitudes toward inclusion: Survey results from elementary school teachers in three southwestern rural school districts. Rural Special Education Quarterly, 22(2), 24-30.

Hays, J. (2008). Teacher as servant: Applications of Greenleaf's servant leadership in higher education. Journal of Global Business Issues, 2(1), 113-134.

Herman, D. V., \& Marlowe, M. (2005). Modeling meaning in life: The teacher as servant leader. Reclaiming Children and Youth, 14(3), 175-178.

Hossain, M. (2012). An overview of inclusive education in the United States. Communication Technology for Students in Special Education and Gifted Programs, 1-25. IGI Global.

Hudson, M., Drowder, D., \& Wood, L. (2013). Review of experimental research on academic learning by students with moderate and severe intellectual disability in general education. Research \& Practice for Persons with Severe Disabilities, 38(1), 17-29.

Kahn, S., \& Lewis, A. R. (2014). Survey on teaching science to K-12 students with disabilities: Teacher preparedness and attitudes. Journal of Science Teacher Education, 25(8), 885-910. https://doi.org/10.1007/s10972-014-9406-z

Kimble, W. J. (2017). Middle school administrator and teacher attitudes towards students with mild to moderate disabilities in the inclusive classroom (Publication No. 1920187842) [Doctoral dissertation, Gardner-Webb University]. ProQuest Dissertations and Theses Global.

Kozleski, E. B., Yu, T., Satter, A. L., Francis, G. L., \& Haines, S. J. (2015). A never ending journey: Inclusive education is a principle of practice, not an end game. Research and Practice for Persons with Severe Disabilities, 40(3), 211-226.

Leatherman, J. M., \& Niemeyer, J. A. (2005). Teachers' attitudes toward inclusion: Factors influencing classroom practice. Journal of Early Childhood Teacher Education, 26(1), 23-36.

McKee, A. (2011). A story of high school inclusion: An ethnographic case study (Publication No. 3473213) [Doctoral dissertation, University of Iowa]. ProQuest Dissertations and Theses Global.

McLeskey, J., \& Waldron, N. L. (2002). Professional development and inclusive schools: Reflections on effective practice. The Teacher Educator, 37(3), 159-172.

Miller, R. (2012). Teacher absence as a leading indicator of student achievement: New national data offer opportunity to examine cost of teacher absence relative to learning loss. Center for American Progress. https://bit.ly/3g2FHNP

National Center for Education Statistics. (2019). The conditions of education 2019. https://nces.ed.gov/pubs2019/2019144.pdf

Noland, A., \& Richards, K. (2015). Servant teaching: An exploration of teacher servant leadership on student outcomes. Journal of the Scholarship of Teaching and Learning, 15(6), 16-38.

Pritchard, K. H. (2014). A comparative study of classroom teachers' perceptions towards inclusion (Publication No. 1630101347) [Doctoral dissertation, Gardner-Webb University]. ProQuest Dissertations and Theses Global.

Rea, P., McLaughlin, V., \& Walther-Thomas, C. (2002). Outcomes for students with learning disabilities in inclusive and pullout programs. Council for Exceptional Children, 68(2), 203-222.

Rosenzweig, K. (2009). Are today's general education teachers prepared to meet the needs of their inclusive students? [Conference session] NERA Conference, Rocky Hill, CT, United States. https://opencommons.uconn.edu/nera_2009/

Rovai, A. P., Baker, J. D., \& Ponton, M. K. (2014). Social science research design and statistics: A practitioner's guide to research methods and IBM SPSS analysis (2nd ed.). Watertree Press. 
Salend, S. J., \& Duhaney, G. (2011). Historical and philosophical changes in the education of students with exceptionalities. In A. F. Rotatori, J. P. Bakken, \& F. E. Obiakor (Eds.), History of Special Education (pp. 1-20). Emerald Group Publishing.

Schmidt, M., \& Vrhovnik, K. (2015). Attitudes of teachers towards the inclusion of children with special needs in primary and secondary schools. Hrvatska Revija za Rehabilitacijska Istraživanja, 51(2), 16-30.

Sahawneh, F. G., \& Benuto, L. T. (2018). The relationship between instructor servant leadership behaviors and satisfaction with instructors in an online setting. Online Learning, 22(1), 107-129.

Shek, D. T. L., \& Chai, W. Y. (2019). Psychometric properties of the service leadership attitude scale in Hong Kong. Frontiers in Psychology, 10(1070), 1-15. https://doi.org/10.3389/fpsyg.2019.01070

Shippen, M. E., Flores, M. M., Crites, S. A., Patterson, D., Ramsey, M. L., Houchins, D. E., \& Jolivette, K. (2011). Classroom structure and teacher efficacy in serving students with disabilities: Differences in elementary and secondary teachers. International Journal of Special Education, 26(3), 36-44.

Spears, L. C. (Ed.). (1998). Robert K. Greenleaf: The power of servant leadership. Berrett-Koehler.

Spears, L. C. (2010). Character and servant leadership: Ten characteristics of effective, caring leaders. The Journal of Virtues \& Leadership, 1(1), 25-30.

van Dierendonck, D. (2011). Servant leadership: A review and synthesis. Journal of Management, 37(4), 12281261.

van Reusen, A. K., Soho, A. R., \& Barker, K. S. (2001). High school teacher attitudes toward inclusion. High School Journal, 84, 7-21.

Wilson, V. A. (2014). Secondary general education teachers' attitudes toward inclusion (Publication No. 3580466) [Doctoral dissertation, Regent University]. ProQuest Dissertations and Theses Global. 